TITLE:

CONTRIBUTIONS TO JAPANESE ASCIDIAN FAUNAXXI. -

BOTRYLLOIDES VIRIDE N. SP., A

NEW GREENISH COMPOUND

ASCIDIAN FROM THE VICINITY OF SETO-

AUTHOR(S):

Tokioka, Takasi

CITATION:

Tokioka, Takasi. CONTRIBUTIONS TO JAPANESE ASCIDIAN FAUNA XXI. -BOTRYLLOIDES VIRIDE N. SP., A NEW GREENISH COMPOUND ASCIDIAN FROM THE VICINITY OF SETO-. PUBLICATIONS OF THE SETO MARINE BIOLOGICAL LABORATORY 1964, 12(4): 281-283

ISSUE DATE:

1964-12-10

URL:

http://hdl.handle.net/2433/175373

RIGHT: 


\title{
CONTRIBUTIONS TO JAPANESE ASCIDIAN FAUNA XXI. BOTRYLLOIDES VIRIDE N. SP., A NEW GREENISH COMPOUND ASCIDIAN FROM THE VICINITY OF SETO ${ }^{1)}$
}

\author{
TAKASI TOKIOKA
}

Seto Marine Biological Laboratory

With 1 Text-figure

Since long ago, I have been aware of the existence of many colonies of a greenish botryllid attached near the low-water mark of the rocky shores, which are facing the open sea and exposed to incessant waves and swells in the vicinity of Seto. Saying more accurately, the colonies are growing mostly at the lower level of the intertidal zone between the upside belt of Sargassum thunbergii (Mertens) O. Kuntze and the downside belt of Hijikia fusiforme (HARVEY) OKamura and covering the basal portions of these sea weeds or found on the shaded cliffs at the same level fouled mainly with algae of the genus Laurencia and the mussel, Septifer bilocularis (LinNé). Thus, the colonies are nearly always under the water but for a short time during the spring tide. First, unusual greenish tint of the colonies led me to the idea to separate them from hitherto known species as a new one, but after morphological examinations the idea was abandoned as there were found no distinctive characters separating them from the common Japanese botryllid, Botrylloides violaceus OKA. I have had many chances of observing Botrylloides colonies in the vicinity of Seto since, usually in the season from spring to summer when I visit the neighbouring rocky shores frequently taking students for field observations. B. violaceus assumes various colourations indeed, monochromatic or blended. For basic colours are known yellow, orange, reddish brown, brown, purplish brown and dark purple, but a greenish tint has never been included. So far as I am aware, the distribution of the above-mentioned greenish botryllid is strictly confined to the low-water mark region of the rocky shore facing the open sea. As is known about Botryllus schlosseri (PAllas), it is very probable that various colour patterns of Botrylloides violaceus are inheritable ones. But the colour pattern of the greenish botryllid seems to be of a special

1) Contributions from the Seto Marine Biological Laboratory, No. 424.

Publ. Seto Mar. Biol. Lab., XII (4), 1964. (Article 20) 
significance ensuring the existence of an ecological variety in the least rather than merely indicate a genetical race of Botrylloides violaceus. The greenish pattern is quite unique and any intermediate or blending colour patterns between this and others are not yet found. Thus I am now inclined to treat such greenish colonies as a separate species for convenience' sake and name it Botrylloides viride for its colouration.

\section{Botrylloides viride n. sp.}

\section{(Japanese name: Midori-itaboya)}

Colonies are encrusting the basal parts of algae or small bivalves so that they are lobated very irregularly. The largest piece of examined colonies is

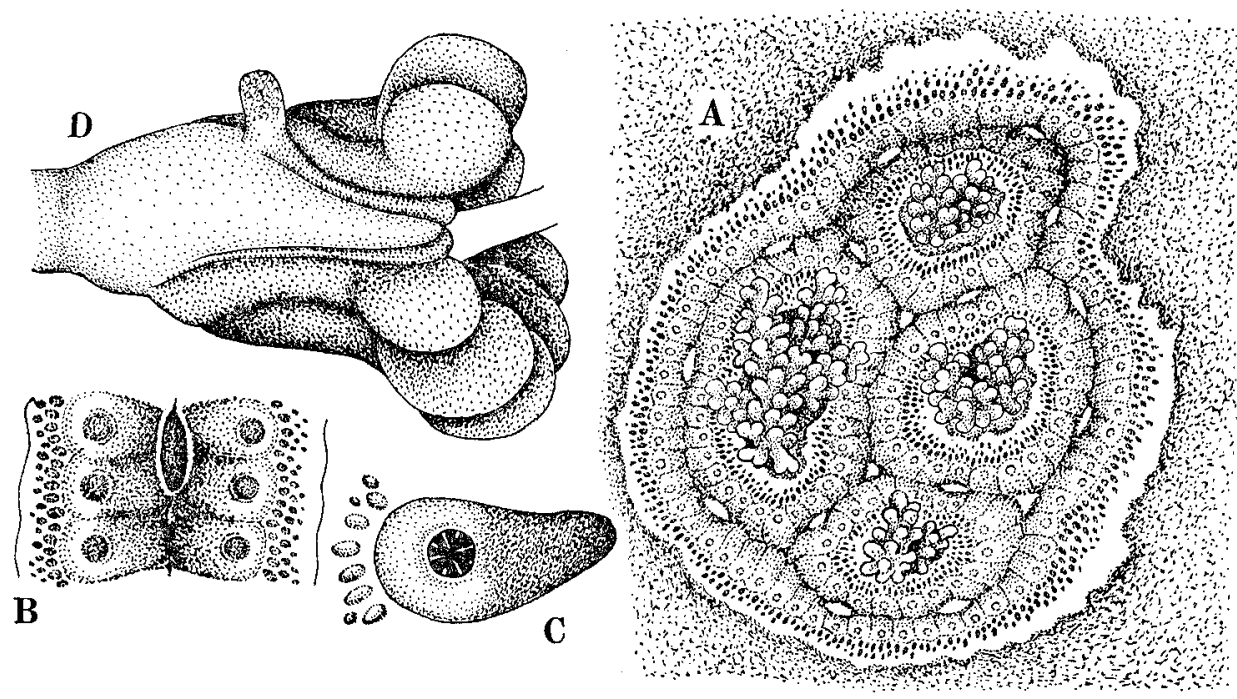

Fig. 1. Botrylloides viride n. sp. A …A colony encrusting between several stocks of Laurencia,

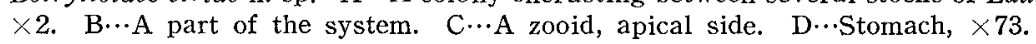

$35 \mathrm{~mm} \times 30 \mathrm{~mm}$ in extent. The thickness of colonies is less than $2 \mathrm{~mm}$. Systems are very elongate as in $B$. violaceus. The test is very soft, gelatinous and translucent.

Zooids are less than $2.5 \mathrm{~mm}$ in a contracted state, though they may attain $3 \mathrm{~mm}$ when extended, buried in the test obliquely. The structure of zooid resembles closely that of $B$. violaceus. There are 10-12 stigmatal rows, each comprising about a dozen stigmata on respective side, the second row does not reach the dorso-median line. Four larger and the same number of smaller tentacles alternate regularly. The stomach is nearly wholly exposed behind the posterior end of the branchial sac and is provided with eight or nine 
longitudinal plications (fig. D) and a pyloric coecum. The coecum seems to be considerably smaller as compared with that of $B$. violaceus and of a simple outline. In $B$. violaceus, the coecum assumes frequently a club-shape with a swollen distal end. The anus opens at the level of the ninth transverse vessel and the anterior edge of the intestinal loop does not extend beyond the level of the ninth or tenth transverse vessel in most zooids, thus the second intestinal loop is rather shallow. In none of the colonies collected from May to July was found any gonad.

When alive, the apical wall of the branchial sac surrounding the branchial aperture is coloured grayish green, while the atrial languet is dark purplish brown (fig. C). Thus the systems formed by zooids of such a colouration are coloured dark purplish brown along the axis, but dull greenish in the periphery (fig. B). Tentacles are whitish and ampullae are pale grayish purple. The colonies turn to uniformly dull purplish brown in preservation in formalin.

The distribution is confined to the wet lower level of the intertidal zone of the rocky shore in this vicinity, facing the open sea and exposed to rough waves and swells. This level is slightly above that of the distribution of Polycitor proliferus (Oka), although these two ascidians may occur mixed together at some places in the region. 